\title{
Anne Holden Rønning and Lene Johannessen, eds., Readings of the Particular. The Postcolonial in the Postnational
}

\section{Saskia Schabio}

\section{(2) OpenEdition}

Journals

Electronic version

URL: https://journals.openedition.org/ces/8452

DOI: $10.4000 /$ ces. 8452

ISSN: 2534-6695

Publisher

SEPC (Société d'études des pays du Commonwealth)

\section{Printed version}

Date of publication: 1 April 2010

Number of pages: 123-124

ISSN: 2270-0633

\section{Electronic reference}

Saskia Schabio, "Anne Holden Rønning and Lene Johannessen, eds., Readings of the Particular. The Postcolonial in the Postnational", Commonwealth Essays and Studies [Online], 32.2 | 2010, Online since 18 December 2021, connection on 31 January 2022. URL: http://journals.openedition.org/ces/8452 ; DOI: https://doi.org/10.4000/ces.8452

This text was automatically generated on 31 January 2022.

\section{$\circledast \oplus \Theta \Theta$}

Commonwealth Essays and Studies is licensed under a Licence Creative Commons Attribution - Pas d'Utilisation Commerciale - Pas de Modification 4.0 International. 


\title{
Anne Holden Rønning and Lene Johannessen, eds., Readings of the Particular. The Postcolonial in the Postnational
}

\author{
Saskia Schabio
}

\section{REFERENCES}

Anne Holden Rønning and Lene Johannessen, eds. Readings of the Particular. The Postcolonial in the Postnational. Amsterdam/ New York: Rodopi, 2007. $262+x v i$ pp. ISBN: 978-90-420-2163-1. €58 / US\$ 81

1 This collection of essays engages with the "problematic and scale of contemporary border-crossings," crystallizing in the range of transcultural identities it produces. It aims to explore the merits of the postcolonial perspective, given its indeterminations (e.g. Dirlik) and tricky overlap with globalization theories. To oppose the latter's abstracting view, the particular is found in the postcolonial aesthetic. Bypassing the impass of any essentialist or comparativist approach to the issue, the editors posit the surplus of the postcolonial aesthetic as a methodological premise. Postcolonial theory is hence affirmed as a theory of the non-generalizable.

2 At the outset, Wenche Ommundsen offers a caveat about the imaginary nature of cultural categories in her carefully argued prelude 'airport fiction,' allegorizing the complexities of global citizenship. In the ensuing section 'Novels and Their Borders,' Priscilla Ringrose probes into concepts of binary and hybrid identities, focusing on recent novels by the descendants of North African migrants in France. Alan Freeman then reconsiders Scotland's novel tradition in light of the perspectives transcultural theories offer. Its ambivalent investment in Britain's imperialist project has catalyzed a specific sense of historical interconnectedness. This is traceable in the historical novel 
(Scott) and Stevenson's Gothic mode, but also in apparently traditional contemporary writing (Boyd). The focus then turns to South Africa and the difficult integration of cultural memories, particularly of female voices, in André Brink's novels (Ute Kauer). Johan Schimanski scrutinizes the proliferating concept of the border in light of what he terms Bessie Head's 'border poetics'. David Bell reads Zakes Mda's treatment of the death ritual as a comment on the uses of the past in debates on the African Renaissance. Ulla Rahbek explores the concept of control in Jean Rhys's writings, which reveals its implication in interpretive categories such as selfhood and authorship, and the mapping of interpretive fields (modernist, colonialist, feminist).

The next section 'Performing Possibilities' sets out with a revision of some of the cruder ideas of the representational paradigm in its relation to gender and the colonial look, advancing the 'image' as a self-conscious mask. Isaac Julien's Looking For Langston suggests the possibility of a non-voyeuristic poetics in its depiction of gay masculinity during the Harlem Renaissance (Asbjørn Grønstad). Drawing on examples from West, East and Southern Africa, Evelyn Lutwama investigates the pertinence of male dominance in precolonial theatre and its (post-) colonial reinforcement, yet heeds simplistic conclusions about the impact of colonialism on modern African gender relations.

4 The three ensuing articles explore Canadianness from multi-ethnic and indigenous perspectives. Expanding on the analogy of stage and nation as imagined spaces, Anne Nothof's survey of postmodern drama establishes national identity as a 'constantly changing syncretic performance'. Attending to their 'excessive literariness', Susan Knutson shows how George Elliott Clarke's Execution Poems complicate Canada's postcolonial identity in their treatment of Titus Andronicus. Kristina Aurylaite reads the aesthetic reconfiguration of the border-zones between white and native spaces in the plays of Daniel David Moses and Tomson Highway through Lefebvre's analysis of social space.

The final section 'Poetic Sites of Intertextuality,' prefaced by a poetological poem (Geoff Page), extends the irrecupability of self-presence defining the intertextual to David Dabydeen's notion of 'creative amnesia' and the performative which is productive of the unpredictable and invites comparison, but does not ascribe primacy, to the Deleuzean-Guattarian revision of space and identity (Erik Falk). Turning to the image of the mask, Charles Armstrong suggests the pervasiveness of Yeats's various personae in the Irish struggle for independence. Ruben Moi explores transtextual relations between two further prominent poets, Muldoon and Heaney, and their contradictory figurations of Northern Ireland. Jacquelynne Modeste discusses the responsibilities of the African American artist to cultural traditions in terms of an '(un)masking of possibilities', establishing an intertextual dialogue between Wright, Ellison, and Murray. Blindness and insight in the triangula of text, history and theory are conceded in the resonant image of the mask, but would require more systematic analysis in some instances. Aesthetic idealism does not result in celebrations of the 'transcultural', but a more sustained consideration of the nation as a necessary frame of reference in postcolonial theorizing would be desirable (Tim Brennan, Laura Chrisman, Benita Parry). The essays speak to one other, although cross-references could have been insinuated more strongly, not least via the suggestive lenses the editors offer, such as the performative and the intertextual. Overall, this collection with its sustained focus on the aesthetic offers insightful readings of literary texts and manages to refine and point beyond 
some of the more predictable conceptual tools available (e.g. Paolo Freire in Bell's discussion of Mda) for the interpretation of global interconnectivity.

\section{AUTHORS}

\section{SASKIA SCHABIO}

Saskia SCHABIo teaches at Stuttgart University, Germany. She has published on Montaigne, Shakespeare, and the 18th century culture of sensibility. Recent work is concerned with revisionary readings of modernity and the transnational. In these areas she has coedited two books, Beyond the Black Atlantic (Routledge, 2006) and Locating Transnational Ideals (Routledge, 2010). 